\title{
Methodological Evaluation Tools of World, National, and Corporate Intangible Assets as the Basis for Competitiveness Management of Companies
}

\author{
Mikhail Egorov \\ Department of Economics Analysis, Statistics and Finance \\ Kuban State University \\ E-mail: e0606@mail.ru \\ Vera Barishnikova \\ Department of World Economics \\ Kuban State University \\ E-mail: barVi-2013@mail.ru
}

\author{
Larisa Egorova \\ Department of World Economics \\ Kuban State University \\ E-mail: 1-egorova-@mail.ru \\ Milena Akhmedova \\ Department of World Economics \\ Kuban State University \\ E-mail: Mili-g1@mail.ru
}

\begin{abstract}
It is hard to overestimate the role of intangible assets in the conditions of growing competitiveness on the global scale. This article reports on the ways to assess the value of intangible assets which is formed at different economic levels (world, national and corporate).
\end{abstract}

Keywords-national and corporate reputation; goodwill; tangible assets; intangible assets (IA); the country's competitiveness; the company's competitiveness

\section{INTRODUCTION}

The expansion of global competition in the world economy highlights such an important issue as formation of world intangible assets (IA) and their interconnection with national intangible assets and, indirectly, with intangible assets of the companies, which form the basis of national economies affecting their level of competitiveness.

An in-depth review of the stated issue - determining the place and role of IA valuation, formed at various economic levels (world, national, corporate), in forming a sustainable competitive position both as a separate company and a country as a whole, - the authors conducted on the basis of the following provisions:

- substantiation of the author's idea about the essence of IA classification

- influence characteristics of the companies' business reputation on forming their sustainable positions in competition

- cost-analysis based determination of effective IA usage to stimulate economic and company's market value growth which provide the increase of competitive stability in the world market

- analysis of world assets value in the context of Europe and Asia, as well as the formation of a rating of the world companies with a high share of IA in the structure of assets and the identification of their influence on forming the world's largest IT companies such as Apple, Google, Facebook, etc. which have impact on global competition.

II. THE ROLE OF A COUNTRY'S BUSINESS REPUTATION IN ENSURING THE SUCCESS OF NATIONAL COMPANIES IN THE

\section{WORLD MARKET COMPETITION}

It seems right to us to classify all intangible assets into three main groups: 1) disclosed IA, which include trademarks as well as licenses; 2) goodwill, which, for instance, can be calculated after the companies' mergers and acquisitions; 3) undisclosed IA or ,,undisclosed value', which is the difference between the market and book value of equity [1].

International experience shows that undisclosed IA and goodwill altogether account for more than $80 \%$ of the value of companies' intangible assets. However, as a rule, both of these indicators are calculated after mergers and acquisitions and, in fact, cannot characterize IA factors. In this regard, they do not interest the regulation subjects in the formation of IA value and, in general, the value of a company's assets.

Therefore, to estimate the role of IA in enhancing the competitiveness of both companies and countries correctly, it is appropriate to use such a progressive methodological approach as a comprehensive one. It enables to assess the degree of influence and therefore, the role of the separate factors in creating the value of intangible assets, and to assess the quality of their interaction.

In international practice, the attempts to classify IA and to identify the sources of their formation are rather common. For instance, in 2001, the UK Department of Trade and Industry (DTI) conducted a study on evaluating IA role in 
As a confirmation can be companies' statistical reports, in creating company value [2]. As a result, 7 sources of IA formation were identified: 1) relationships 2) knowledge 3) leadership qualities and communications 4) culture and values 5) reputation and credibility 6) skills and competence 7) processes and systems. We believe that the sources of IA formation identified by the UK DTI reflect the current reality most adequately and can be used in our study.

A strong world economy is a combination of strong national brands. There are distinctive characteristics at the core of any national brand as well as any corporate brand: culture, national values, people representing this nation and also state and expectations of the market. Those countries that have a clear strategy and are able to present their national brand in each of these areas right often manage to create a significant competitive advantage in the world market.

It should be noted that, in this regard, a clearly developed and effectively implemented national brand development strategy becomes of particular importance, which ensures "the country of origin effect" meaning the production of a product, goods or service in the given country perceived as more valuable. Due to this, the demand is growing, which enables national manufacturers and suppliers to set higher prices creating the basis for the growth of companies' value in this country. [3]

At the same time, it should be noted that the opposite is also true, when strong corporate brands are behind each highly valuable national brand. They are able to work in harmony within clearly formulated national brand development strategy, which enables to create an additional value of IA that increases the market value of a company.

The post-industrial development of the world economy created conditions for intensive development of the tertiary sector industries, in which intangible assets are mainly created. It should be noted that in all highly developed countries tertiary sector takes leading position in the structure of national economy and, therefore, plays the role of a driver in creating national brand and ensuring the country's economic growth.

Here we should clarify what we mean by national brand as an element of IA.

In scientific economic literature the essence of the term "brand" consists in characteristics of distinctive name and/or symbol, for instance, an emblem, trademark, package design, etc, serving to identify a product or service. However, such an interpretation of brand is applicable only within the marketing concept, which differs from the legal concept of a trademark. In business practice, legal protection of a trademark is carried out on the basis of its registration in the Patent Office of the Russian Federation and includes receiving of a trademark certificate valid for 10 years. The existing of a brand is not reflected in regulatory documents but exists only in the ideas of potential customers. Therefore, brand, being an important structural element of ta company's goodwill, is one of the most "non-material", undefined intangible assets. which there is almost no data on business reputation as an integral part of IA. For instance, according to the National Credit Bureau, in 2014 in Russia from more than 225,000 organizations registered in its system only 4758 reported on "Goodwill" ("Table I").

TABLE I. “GOODWILL” ASSET CHARACTERISTIC OF THE RUSSIAN COMPANIES IN TERMS OF THE INDUSTRIES, 2017 [4]

\begin{tabular}{|l|l|}
\hline \multicolumn{1}{|c|}{ Industry name } & $\begin{array}{c}\text { The share of "goodwill" in } \\
\text { balance currency, \% }\end{array}$ \\
\hline Trade, catering & 0,66 \\
\hline Industry & $0,9(\mathrm{~min})$ \\
\hline Construction & 0,30 \\
\hline Logistics & 0,97 \\
\hline Public utilities & 1,55 \\
\hline Transport and communication & 0,12 \\
\hline Agriculture & $14,82(\max )$ \\
\hline Forestry & 1,52 \\
\hline
\end{tabular}

Business reputation, also known as "goodwill" is an indicator, which characterizes the quality of any company at any time. That is why this indicator can have both positive and negative values. Therefore, it becomes very important to enhance the goodwill value management as an asset, which helps to obtain additional competitive advantages and strengthen a company's position on internal and external markets. [5]

From the business point of view, a good business reputation means big money, big investments into this element, which provide ten or even twenty times bigger feedback. For instance, a reliable goodwill makes it possible to take out a loan against smaller deposit. Moreover, company's goodwill allows it to take advantage of monopoly and assign a higher price to its products and services. But, on the other hand, maintaining high goodwill requires constant investments not only into the quality of goods and services but also into service, image, trademark advertising, etc.

The idea of companies' goodwill both in Russian and foreign business is formed by the ratings compiled by special consulting companies, for instance, by national consulting company Expert, etc. The demand for business reputation ratings of Russian companies is caused not only by the great interest for this asset from the companies' top management but also from business partners, competitors and, of course, consumers ("Table II"). 
TABLE II. BUSINESS REPUTATION RATING OF 254 RUSSIAN COMPANIES, 2017 [6]

\begin{tabular}{|l|l|}
\hline \multicolumn{1}{|c|}{ Components of reputation } & Points* \\
\hline $\begin{array}{l}\text { One should take care of a company's reputation no less } \\
\text { than of its assets }\end{array}$ & 3,92 \\
\hline $\begin{array}{l}\text { A company with a good business reputation has } \\
\text { competitive advantages in the market }\end{array}$ & 3,32 \\
\hline $\begin{array}{l}\text { Good reputation allows to attract cheaper loans with } \\
\text { smaller deposit }\end{array}$ & 3,20 \\
\hline $\begin{array}{l}\text { The more famous the company, the higher its } \\
\text { reputation }\end{array}$ & 2,47 \\
\hline $\begin{array}{l}\text { Goodwill is formed with the help of ethical } \\
\text { relationships with partners }\end{array}$ & 2,81 \\
\hline $\begin{array}{l}\text { The quality of goods and services is the basis of a high } \\
\text { reputation }\end{array}$ & 3,97 \\
\hline $\begin{array}{l}\text { High efficiency of a company's top management and } \\
\text { its good reputation contribute to formation of a } \\
\text { company's goodwill }\end{array}$ & 3,61 \\
\hline \multicolumn{2}{|l}{} \\
\hline
\end{tabular}

The assessment was carried out on a four-point system: 4 - completely agree, 3 - partially agree, 2 - partially disagree, 1 - completely disagree.

The research of the national brand value in the world is conducted by a fairly large number of expert companies. For instance, Brand Finance Nation Brands, which, in the result of a rating study conducted in 2015 from 20 countries leading in corporate IA, identified 12 countries characterized by a strong national brand. Among them, there is the USA, UK, France, Switzerland, etc.

It should be noted that in the practice of developed countries such elements as know-how, business relations, IA, top management, brands, etc. are included in the IA structure, which comprise a larger share of the assets value in the vast majority of companies than tangible assets such as equipment, infrastructure, etc.

We can reasonably claim that the key to economic success in the long term both of separate companies and of countries as a whole is to increase the efficiency in organizing and managing intangible assets.

\section{PERSPECTIVE DIRECTIONS FOR EFFICIENT USE OF INTANGIBLE ASSETS FOR THE GROWTH OF NATIONAL COMPANIES' MARKET VALUE}

It should be noted that the efficient use of intangible assets for stimulating economic growth and increasing a company's market value must be preceded by understanding and deep cost analysis of what they are.

For instance, it is important to have a clear idea of composition and structure of a corporate brand. It is often one of the most valuable undisclosed intangible assets of a company. Despite its immateriality, it can be managed, and interested investors can allocate to it.

At the same time, strong brands create powerful brand equity altogether with their customer base. This, in turn, enables companies to raise prices on goods and services and also to overtake competitors in terms of sales, to develop and strengthen customers' loyalty to the brand. Altogether it creates value and ensures market and shareholder value of a company.

Practice shows that, as a rule, companies' top managers, including marketing managers, have no adequate idea of the impact their intangible assets have on business value, for instance, brand or relations with the customers, etc.

The above-mentioned consulting company Brand Finance conducted a study of 58800 companies, which represented more than 120 countries and financial stocks. Total value of the companies' assets involved into the study at the beginning of 2015 amounted to $\$ 71$ trillion, including: \$ 33,5 trillion - net tangible assets; $\$ 11$ trillion - disclosed intangible assets; \$26,5 trillion was the so-called "undisclosed value".

The analysis showed that the companies' total value for the study period increased by 40,3 trillion, among which: $\$ 22,2$ trillion - net tangible assets; $\$ 7,7$ trillion - disclosed intangible assets (including goodwill); $\$ 10,5$ trillion "undisclosed value". ("Fig. 1")

\section{Global Enterprise Value Breakdown (\%)}

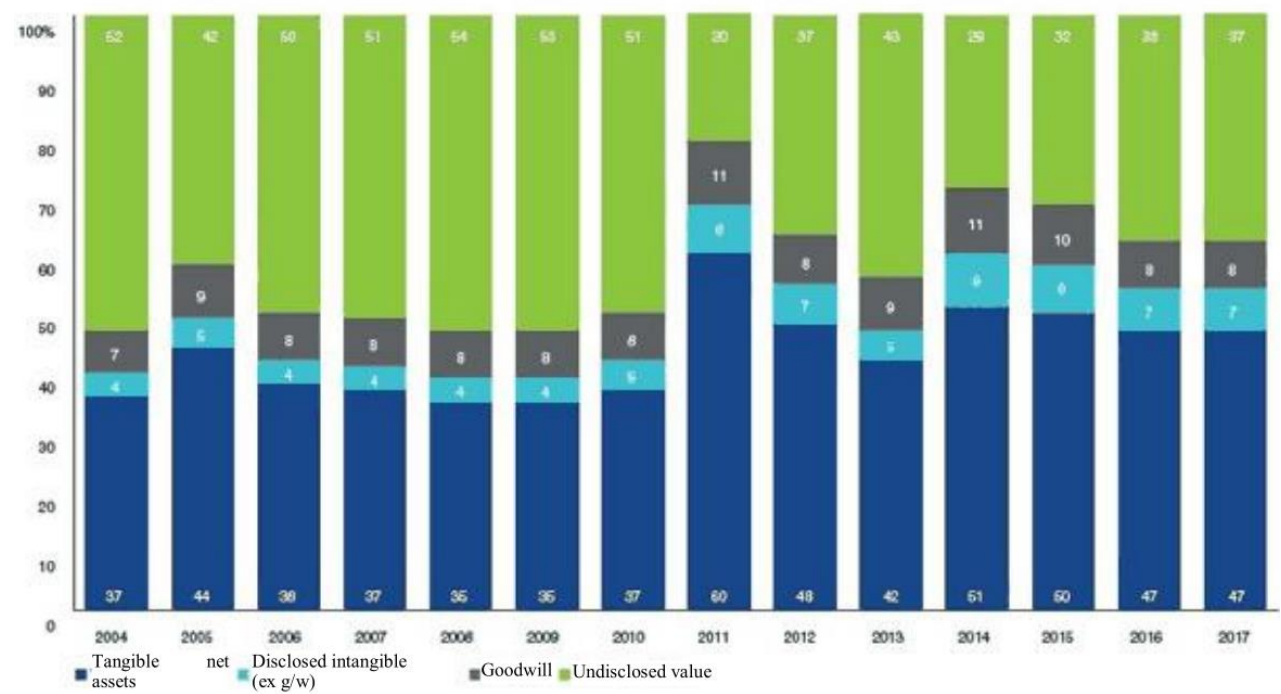

Fig. 1. Dynamics of value changes in assets' structure of the foreign companies, 2004-2017 [7]. 
The analysis of value changes in assets' structure of 58800 foreign countries in terms of the industries from 2004 to 2017 demonstrated the following: $\$ 6,7$ trillion in growth amounted to the banking sector; $\$ 1,8$ trillion pharmaceutical sector; $\$ 1,6$ trillion - oil and gas sector. The share of credit and savings sector, on the contrary, decreased by $24 \%$, the value of their assets approached $\$ 70$ billion.

In general, the total value of the studied companies amounted to $\$ 71$ trillion. Whereby $18 \%$ of this amount was concentrated in 50 largest companies, and only half of the total value in 400 largest companies, which represented $0,68 \%$ of the total number of companies. ("Fig.2")

\section{Top 50 Sectors by EV (US\$ billion)}

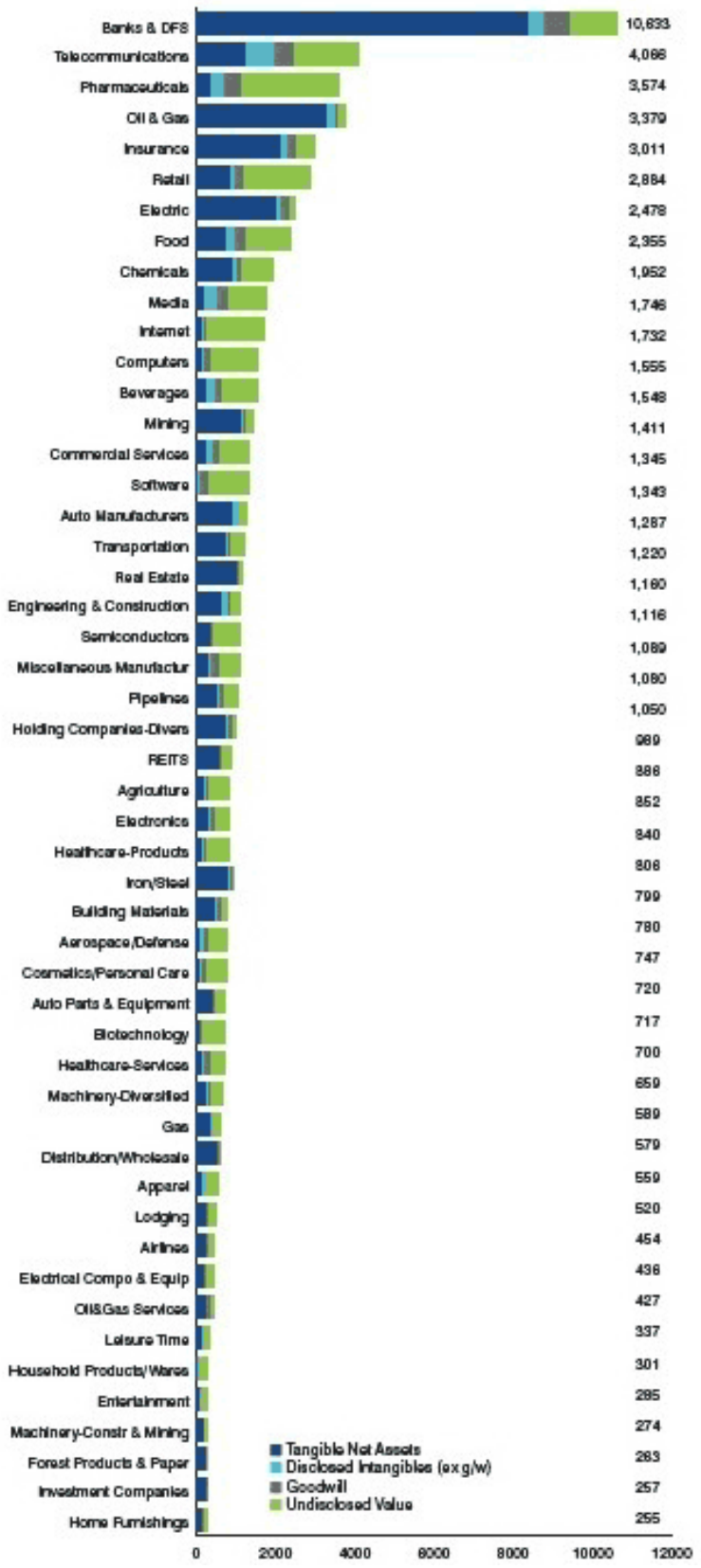

Fig. 2. Average annual distribution of assets in the foreign companies under study according to the industry principle, 2001-2017 [7].
As it can be seen from the figure, banking sector is the biggest one, surpassing the following telecommunication sector by more than 2 times in assets value. Moreover, this sector has also the largest growth, which has been $\$ 2,957$ trillion for the last 5 years. It was ensured, on the one hand, by an increase in net tangible assets by $\$ 3,832$ trillion and, on the other hand, by a simultaneous decrease in the IA value by $\$ 875$ billion, which indicates significant write-offs and expenses because of IA devaluation of the companies in banking sector.

The pharmaceutical sector, in which $\$ 1,808$ trillion of the assets value was received as the result of increased expenses on medication in the world, took the second place by the growth of companies' assets value. At the end of 2017 these expenses amounted to $\$ 1,97-\$ 2,2$ trillion, which is three times higher than the indicators of the most efficient 2007 (\$731 billion).

Internet sector ranked third by the growth of assets value, in which the growth was $\$ 1,169$ trillion, among which: $\$ 51$ billion - net tangible assets; $\$ 1,118$ trillion - intangible assets). The success of this sector's companies, for instance, Facebook and Alibaba after their release in IPO ensured investing into their assets, which is likely to continue in the medium term.

At the same time, the analysis showed that oil and gas sector has become the leader in maximum losses over the last 5 years, where the total value of companies' assets decreased by $\$ 1,444$ trillion. It was connected with a sharp decrease in IA assets value and low growth rates of net tangible assets. The negative dynamics of oil prices in recent years (since mid-2014 they have been cut more than in half), entails a further decrease in assets value of the companies of this world economy sector.

The second and the third places in the rating according to the economic recession level belong to the following sectors: electricity, where the decrease was $\$ 769$ billion; mining industry, where it was $\$ 744$ billion. It should be noted that if in electricity sector assets value decrease was equally related to a decrease in their tangible and intangible value, then the assets value decrease in mining industry sector was primarily due to the decline in IA assets value.

Some peculiarity should be noted in the dynamics of changes in the value of telecommunications companies. These companies are the leaders among the companies in the world with the most valuable and undisclosed intangible assets taking 8 out of 20 places in the list of leaders according to these criteria. When it comes to mergers and acquisitions in telecommunications, the most important criteria to estimate a company are the existing relationships with the clients, as well as contracts, licenses on providing mobile services, trademark rights, which refers to intangible assets. In addition, their goodwill plays a significant role in ensuring the growth of the value of telecommunication companies' assets as an indicator of rather high competitive potential manifested in a large market share, new types of services, etc. 
India and Switzerland are also among the leaders in the rating of the "most intangible" countries. India has achieved such a position due to its leadership in the development of personal computer equipment whereas Switzerland - in pharmaceutical sphere. We should mention that these two sectors are characterized by a significant share of intangible assets represented by intellectual property.

The top five countries with the biggest share of tangible assets are almost entirely represented by Eastern Europe, which are Bosnia and Herzegovina; Russia; Kazakhstan; Serbia; Bulgaria. On the one hand, this situation reflects countries' industry priorities of development and on the other hand, low representation of such industries as media, software development and pharmaceuticals. For instance, top 10 Russian largest companies are representatives of oil and gas, banking or mining industries.

Therefore, countries' rating by disclosed intangible assets is as follows: Europe is at the first place among the companies with the highest value share of disclosed IA. This is France, with $35 \%$ of disclosed IA of the total value of the companies; Belgium -32\%; Italy - 29\%; Portugal - 27\%; Germany $-24 \%$. It should be noted that such situation is to some extent the result of the mergers and acquisitions policies, which the companies of these countries pursued actively in the years before economic recession, which allowed them to accumulate quite significant goodwill and many intangible assets.

This, by the beginning of 2015 the total value of the UK companies' assets has increased by $\$ 165$ billion compared to the same indicator at the beginning of 2014. This was the result of an equal increase in net tangible assets and disclosed intangible assets, although unaccounted assets showed 5\% decrease.

However, in terms of the growth rate of IA value at the beginning of 2015, developing countries of the first and second stages of development became the leaders. These are Thailand - 25,9\% growth; Russia - 25,6\%; Brazil - 24,8\%; Vietnam $-24,5 \%$; Chile $-22,9 \%$ growth.

The value of disclosed IA of Russian companies increased by $25,6 \%$ over five years taken under study (20092017). Despite such a high increase, the capital structure of Russian companies has not changed much and consists mainly of tangible assets. It happens because the development of "material" industries is more intensive, which include oil and gas, banking and mining sectors. They are represented by 10 largest Russian companies [8].

As for the role of IA in the development of economy in Eastern countries, there we can talk about its flow from industrial sector to service sector. In the future, it may lead to a significant increase in IA value in the total value of the companies' intangible assets of these countries.

In general, summing up all the mentioned above, we can draw the following conclusions:

- Nowadays we can mark the increased importance of intangible assets for companies, national economic formed and operate in the USA, and, as it is known, the Internet is the most "intangible" business. 
complexes and for the world economy. These assets make up about $50 \%$ of companies' value in the world;

- The participants in business processes, who seek to enhance the mechanism for creating IA value, should pay special attention to the analysis of factors stimulating the growth of intangible assets and the to the choice of influencing tools.

- Special role in forming the conditions for the growth of IA value should be played by the management and regulation subjects at all the levels, from the company level to the world level. For instance, representatives of legislative bodies, basing on information about the necessity to regulate market competition, should take the necessary measures to improve antitrust laws and antitrust policy for a widespread use of IA in the development of entrepreneurial activity, in emergence of new business models, etc.;

- There is a need to enhance management tools of market work with the most important intangible assets;

- To increase a company's success in the competition, its managers should understand the role of each factor in the formation and management of intangible assets.

\section{REFERENCES}

[1] Egorov M.V. Metodologicheskie aspekty ocenki nematerial'nyh, neosjazaemyh aktivov v mehanizm e investirovanija predprijatij// Jekonomika ustojchivogo razvitija. [Methodological Aspects of the Assessment of Non-material, Intangible Assets in the Mechanism of Enterprise Investment // Economics of Sustainable Development.] №2(22), 2015, pp. 82-89

[2] Creating Value from your Intangible Assets: Unlocking your True Potential. UK Department of Industry and Commerce Report. Available at: http://www.marketing.spb.ru/mr/business/

[3] Egorov M.V. Intellektual'nyj kapital v mezhdunarodnoj praktike i ego vlijanie na stoimost' biznesa// Mezhdunarodnaja jekonomika [Intellectual Capital in International Practice and Its Impact on Business Value // International Economics.] i.2. Monography, Krasnodar, Ekoinvest Publ., 2012, pp. 445-475

[4] National Credit Bureau of the Russian Federation. Available at: http://www.creditnet.ru/pyper/

[5] Egorov M.V., Zebelyan K.I. Gudvill kak konkurentnoe preimushhestvo kompanij na mirovom rynke gorno-metallurgicheskoj promyshlennosti// Jekonomika ustochivogo razvitija [Goodwill as a Competitive Advantage for Companies in the Global Mining and Metal Market // Economics of Sustainable Development.] №2(22), 2015, pp. 89-93

[6] National Consulting Company "Expert". Available at: http://www.txpert-otsenka.ru/intellekt/

[7] International Consulting Company "Brand Finance". Available at: http://www.marketing.spb.ru/mr/business/Global_Intangible_Financi al_Trasker.htm.

[8] P. Catalfo Methodological Accounting Tools for the Evaluation of Intangibles Management in Research Institutions: Some Empirical Remarks // Journal of Service Science and Management 2015. №08(04):638-648 